\title{
Response of Two Garlic Cultivars to Foliar Nutrition under Irrigation with Saline Water
}

\author{
Nashwa I. Abo El-Fadel* and Wafaa H. Mohamed** \\ *Sabaheya Horticultural Research Station, Horticultural \\ Research Institute, Agricultural Research center, Giza and \\ *** Department of Soils and Agricultural Chemistry, Faculty of \\ Agriculture, Saba Basha, Alexandria University, Alexandria, \\ Egypt.
}

\begin{abstract}
7 WO pot experiments were conducted during the two winter 1 seasons of 2010/2011 and 2011/2012 at the soil salinity lab. Alexandria, Agricultural Research Center, to study the effect of irrigation with saline water and foliar nutrition on the vegetative growth, chemical content and green yield of two garlic cultivars. Treatments were the combination of two cultivars; sids 40 and Baladi, two treatments foliar and three saline irrigation water treatments, i.e., 1500,2500 and $3500 \mathrm{mg} / \mathrm{L}$ and well water (control). The results indicated that $\mathrm{cv}$. sids 40 recorded the highest values of plant height in the two seasons. No. of leaves / plant had non-significant differences between the two cultivars in the two seasons. On the other hand, the results also, indicated that $\mathrm{cv}$. Baladi recorded the highest values of fresh weight of (bulbs and cloves) and No. of cloves/bulb compared with other cultivar (sids 40) in the two seasons. The highest values of $\mathrm{N}$ and $\mathrm{P}$ uptake were recorded by $\mathrm{cv}$. Baladi followed by cv. sids 40 . Thus, cv. Baladi was the most salt tolerant compared with cv. sids 40 . Increasing salinity of irrigation water decreased vegetative growth and green yield up to the highest concentration $(3500 \mathrm{mg} / \mathrm{L}) . \mathrm{N}$ and $\mathrm{P}$ uptake were gradually and significantly decreased by increasing irrigation water salinity up to its highest level. Vegetative growth, chemical content and green yield, significantly improved with nutrient applied through foliar spray. The combined effect among cultivars, foliar nutrition and salinity concentrations of irrigation water had significant and highly significant effect on fresh weight of cloves and No. of cloves/ bulbs. These results were true and similar in the two seasons of the experiment.The interaction had highly significant effect on protein \% content and N, P and K uptake by cloves of garlic plants.
\end{abstract}

Garlic (Allium sativum L.) has been known as one of the oldest known horticultural crops in the old world. It is one of the most important bulb crops in Egypt which is cultivated for both local consumption and export. It is commonly used as a spice or condiment as well as for medical purposes (Hassan et al., 2011).

Egypt is a part of an arid belt extending from the Atlantic to Central Asia. The Nile is the main and almost the exclusive source of fresh water. In Egypt, 
more than $33 \%$ of irrigated lands were affected by salinity (Ghassemi et al., 1995). Salinity is one of several environmental factors which can limit the successful production or even survival of various crops (Hassan et al., 2001). The ever increasing demand for agricultural products is requiring reassessment of the production potential of low quality land and water resources (Epstein et al., 1980). The initial effect of salinity at cellular level is due to its osmotic effects. In a 2-year study, Francois (1994) found that the threshold salinity of garlic was $3.9 \mathrm{dS} \mathrm{m}^{-1}$ and at $7.4 \mathrm{dS} \mathrm{m}^{-1}$ the yield was reduced by $50 \%$. All yield components, bulb weight and diameter, and plants per unit area, were reduced with increasing salinity, as well as percent solids which is a major component of bulb quality.

Application of nutrients has an economic role in decreasing the cost of some soluble nutrients which unfortunately may be converted to insoluble forms. So, foliar spray may overcomes this problem (Hegab et al., 1987).Foliar application is very important environmental goal as it minimizes pollution of soil with mineral fertilizers and hence reducing its mobility to underground water or surface water (Abdelgadir et al., 2010 and Hassan et al., 2011). On the other hand, foliar application of nutrient solution ameliorate the negative effects of salinity by enhancing the availability of some other essential cations and phytohormones which play an important role in regulation of stomata (Sage and Reid, 1994).Also, foliar application of fertilizers saves irrigation water, which would otherwise be necessary to carry out in order to dissolve and distribute well the fertilizer wherever the quality of water is not sufficiently good.

Therefore, this work was conducted to evaluate the foliar application of green house solution on the growth, yield and some chemical constituents of two garlic cultivars under different levels of irrigation water salinity.

\section{Material and Method}

A pot trial was conducted during two successive seasons of 2010/2011 and 2011/2012 at the soil salinity lab. Alexandria, Agricultural Research Center. Two garlic cultivars (sids 40 and Baladi) were planted on the first week of October in both of the two growing seasons. Uniformed cloves were soaked in running water for $24 \mathrm{hr}$ before planting and planted in pots (four plant / pot).These pots $(0.50 \mathrm{~m}$ in diameter and $0.40 \mathrm{~m}$ deep), having basal holes for leaching irrigation water,were filled with $4.0 \mathrm{~kg}$ clay soil / pot. Soil physical properties were determined using the procedures described by Black et al. (1981) while soil chemical properties were measured according to the procedures described by Jackson (1973). The obtained results were presented in Table 1. 
TABLE 1. Physical properties and chemical analysis of the tested soil.

\begin{tabular}{|c|c|c|c|c|c|}
\hline properties & $\begin{array}{c}2010 / \\
2011 \\
\end{array}$ & $\begin{array}{c}2011 / \\
2012 \\
\end{array}$ & properties & $\begin{array}{c}2010 / \\
2011 \\
\end{array}$ & $\begin{array}{l}2011 / \\
2012\end{array}$ \\
\hline Texture & clay & clay & Total nitrogen $(\mathrm{N}), \%$ & 0.066 & 0.053 \\
\hline Sand, $\%$ & 25.0 & 24.28 & \multicolumn{2}{|c|}{ Nutrients available, $\mathrm{mg} / \mathrm{kg}^{-1}$} & \\
\hline Silt, \% & 27.0 & 28.65 & Extractable $\mathrm{P}$ & 9.29 & 8.87 \\
\hline Clay, \% & 48.0 & 47.07 & Extractable K & 125 & 120 \\
\hline $\mathrm{pH}$ & 7.65 & 7.87 & DTPA-extractable $(\mathrm{Fe})$ & 2.29 & 2.11 \\
\hline $\left.\mathrm{EC},(\mathrm{dS} \mathrm{m})^{-1}\right)$ & 1.83 & 2.42 & DTPA-extractable $(\mathrm{Cu})$ & 0.84 & 0.62 \\
\hline $\mathrm{CaCO}_{3} \%$ & 8.22 & 9.75 & DTPA-extractable $(\mathrm{Mn})$ & 3.10 & 3.44 \\
\hline Organic matter, $\%$ & 0.83 & 0.78 & DTPA-extractable $(\mathrm{Zn})$ & 1.01 & 1.15 \\
\hline
\end{tabular}

All the plants were fertilized with the recommended doses of $\mathrm{N}, \mathrm{P}$ and $\mathrm{K}$. Plants of every pot received mineral fertilization; $4.0 \mathrm{gm}$ ammonium nitrate $(33.5 \% \mathrm{~N}), 4.0 \mathrm{gm}$ calcium superphosphate $\left(15.5 \% \quad \mathrm{P}_{2} \mathrm{O}_{5}\right)$ and potassium sulphate $\left(48 \% \quad \mathrm{~K}_{2} \mathrm{O}\right)$ was added monthly at a rate of $2.0 \mathrm{gm} / \mathrm{pot}$. The experimental design was presented as a randomized complete blocks design with four replicates. Each experiment included 16 treatments consisted of two cultivars; sids 40. and Baladi. Two treatments foliar and nonfoliar and four levels of saline irrigation water ( prepared from sea water) at 1500, 2500 and 3500 $\mathrm{mg} / \mathrm{L}$ beside the control (one irrigation with Fresh water). The seeds were sown in pots under non saline condition and saline water irrigation was started at three leaf stage after germination to get seedlings of equal size. After thinning only three seedlings were kept in each pot for further work. Plants were equally irrigated with well water for four weeks and the irrigation with different concentration of saline water was applied after one month from planting. Control (irrigation water of the location) and three dilutions of sea water, i.e., 1500, 2500 and $3500 \mathrm{mg} / \mathrm{L}$. The salinity of the sea water was $34000 \mathrm{mg} / \mathrm{L}$ total salts which contained $4000 \mathrm{mg} / \mathrm{L} \mathrm{Ca}, 1272.0 \mathrm{mg} / \mathrm{L} \mathrm{Mg}, 10300.0 \mathrm{mg} / \mathrm{L} \mathrm{Na}, 380.0 \mathrm{mg} / \mathrm{L} \mathrm{K}$, $12.0 \mathrm{mg} / \mathrm{L} \mathrm{CO}_{3}, 97.9 \mathrm{mg} / \mathrm{L} \mathrm{HCO}_{3}, 2496.0 \mathrm{mg} / \mathrm{L} \mathrm{SO}_{4}$ and $19312.0 \mathrm{mg} / \mathrm{L} \mathrm{Cl}$.

The chemical composition of the foliar application solution (green house solution) was: N (20\%), P (20\%), K (20\%), Ca (7.5\%), Fe (4.0\%), Cu (5.0\%), Zn (5\%), Mn (5.0\%), B (0.2\%) and Mo (0.05\%). Foliar nutrition was sprayed to the plants twice a week at 30 days from planting up to 90 days. Plants under saline treatments were irrigated with $3.5 \mathrm{~L}$ of their respective sea salt solution ensuring about $40 \%$ leaching requirement. Non foliar treatment, plants were sprayed with Fresh water. Spraying was carried out with a hand pressure sprayer. The plants were sprayed with solutions with uniform coverage until the leaves were completely wet and the solution ran off the leaves. At the time of spraying other plants were covered with plastic sheet to prevent the contamination of sprayed nutrients.

At harvesting and after removal from the soil, all plants were placed on plastic sheets to determine vegetative growth characters green yield as fresh 
weigh of bulbs (g/plant) and fresh weigh of cloves (g/plant) of the two cultivars of garlic were recoded. Three plants from each treatment were randomly taken at 120 days after planting. The plant height and number of leaves / plant was recorded. The tops were removed by cutting those $4.0 \mathrm{~cm}$ above the bulb. After the bulbs were weighed (g/plant), all cloves of taken bulbs of each treatment were used to determine, i.e., clove weight ( $\mathrm{g} / \mathrm{plant}$ ) and number of cloves per bulb. An additional sample of bulbs was used for elemental analysis. For these analyses, the bulbs were dried at $70^{\circ} \mathrm{C}$ for $72 \mathrm{hr}$, ground, wet digested by using $\mathrm{H}_{2} \mathrm{SO}_{4}-\mathrm{H}_{2} \mathrm{O}_{2}$ (Lowther, 1980) and $\mathrm{N}, \mathrm{P}$ and $\mathrm{K}$ contents were determined according to Jackson (1973). Also, the uptake in bulbs of these nutrients were calculated (g/plant). Total protein $(\%)$ was calculated by multiplying total nitrogen x 6.25 .

All of the obtained data were subjected to statistical analysis of variance according to Snedecor and Cochran (1980) and the least significant difference (L.C.D) was calculated as mentioned by Gomez and Gomez (1984).

\section{Results and Discussion}

\section{Cultivars}

Data in Tables 2, 3 and 4 showed the vegetative growth, yield and its components of the two cultivars of garlic (sids 40 and Baladi) expressed as plant height, bulb weight, cloves weight, No. of cloves/ bulb in the two seasons.

Plant height in the first season was significantly as affected by two cultivars, while plant height was not significantly as affected by two cultivars in the second season. Data also showed that, No. of leaves / plant was not significantly affected by the two cultivars in the two seasons (Tables 2 and 3). The results indicated that Baladi $\mathrm{cv}$. was the best in its green yield (bulb weight, cloves weight, No. of cloves/ bulb weight) as compared with cv.sids 40. These differences among cultivars were statistical in the two seasons of the experiment.This might be due to the genetic differences among cultivars and their ability for utilizing the environmental sources especially light, $\mathrm{CO}_{2}$, water and nutrients.

$\mathrm{N}$ and $\mathrm{P}$ uptake $\left(\mathrm{g} / \mathrm{kg}^{-1}\right)$ were statistically varied among the tested cultivars (Table 4). The highest values of $\mathrm{N}$ and $\mathrm{P}$ uptake were recorded by cv. Baladi followed by cv. sids 40 , while the $\mathrm{K}$ uptake was not statistically influenced by the tested cultivars. Data in Table 4 also showed, significant differences between protein\% content at the two cultivars of garlic. The highest protein \% content was recorded by cv. Baladi followed by cv.sids 40 . This might be due to the genetic differences among cultivars and their ability for utilizing the environmental sources especially light, $\mathrm{CO}_{2}$, water and nutrients. 
RESPONSE OF TWO GARLIC CULTIVARS TO FOLIAR NUTRITION ... 211

TABLE 2. Effects of foliar nutrition and water salinity levels on vegetative growth and yield components of the two genotypes of garlic during season of 2010/2011.

\begin{tabular}{|c|c|c|c|c|c|c|c|}
\hline \multirow[t]{2}{*}{ Cultivars } & \multirow[t]{2}{*}{ Foliar } & \multirow{2}{*}{$\begin{array}{c}\text { water } \\
\text { Salinity } \\
\text { mg/L }\end{array}$} & \multirow{2}{*}{$\begin{array}{l}\text { Plant } \\
\text { height } \\
(\mathrm{cm})\end{array}$} & \multirow{2}{*}{$\begin{array}{l}\text { No. of } \\
\text { leaves / } \\
\text { plant }\end{array}$} & \multicolumn{2}{|c|}{$\begin{array}{c}\text { Fresh weigh } \\
\text { (g/plant) }\end{array}$} & \multirow{2}{*}{$\begin{array}{c}\text { No. of } \\
\text { cloves/ } \\
\text { bulb }\end{array}$} \\
\hline & & & & & bulbs & cloves & \\
\hline \multirow{8}{*}{ Baladi cv. } & \multirow{4}{*}{ Non foliar } & Cont. & 36.67 & 10.33 & 73.10 & 5.96 & 37.33 \\
\hline & & 1500 & 38.33 & 7.67 & 57.03 & 5.67 & 28.67 \\
\hline & & 2500 & 38.33 & 8.67 & 49.83 & 4.94 & 32.67 \\
\hline & & 3500 & 28.00 & 7.67 & 52.17 & 4.15 & 22.00 \\
\hline & \multirow{4}{*}{ Foliar } & Cont. & 38.67 & 15.33 & 72.83 & 6.39 & 44.67 \\
\hline & & 1500 & 45.00 & 9.00 & 63.60 & 6.20 & 34.68 \\
\hline & & 2500 & 44.00 & 7.67 & 61.80 & 6.26 & 32.00 \\
\hline & & 3500 & 37.00 & 7.33 & 57.70 & 6.91 & 31.66 \\
\hline \multirow{8}{*}{ Sids $40 \mathrm{cv}$. } & \multirow{4}{*}{ Non foliar } & Cont. & 47.67 & 9.67 & 59.63 & 5.07 & 14.33 \\
\hline & & 1500 & 44.33 & 8.33 & 51.73 & 5.37 & 13.00 \\
\hline & & 2500 & 40.33 & 7.67 & 45.00 & 4.95 & 13.67 \\
\hline & & 3500 & 29.33 & 7.33 & 44.73 & 2.86 & 12.00 \\
\hline & \multirow{4}{*}{ Foliar } & Cont. & 52.33 & 11.00 & 61.40 & 6.44 & 15.00 \\
\hline & & 1500 & 49.67 & 11.00 & 61.04 & 5.71 & 13.66 \\
\hline & & 2500 & 53.00 & 9.00 & 58.84 & 6.83 & 13.33 \\
\hline & & 3500 & 38.67 & 7.67 & 51.47 & 6.13 & 12.00 \\
\hline \multicolumn{8}{|c|}{ Mean effect of cultivars } \\
\hline \multirow{3}{*}{$\begin{array}{l}\frac{\text { Cultivars }}{\text { Baladi cv. }} \\
\text { Sids } 40 \mathrm{cv} \text {. }\end{array}$} & & & & & & & \\
\hline & & & $38.25 \mathrm{~b}$ & $9.29 \mathrm{a}$ & $61.01 \mathrm{a}$ & $5.81 \mathrm{a}$ & $32.96 \mathrm{a}$ \\
\hline & & & $44.42 \mathrm{a}$ & $9.63 \mathrm{a}$ & $54.23 \mathrm{~b}$ & $5.42 \mathrm{~b}$ & $13.38 \mathrm{~b}$ \\
\hline \multicolumn{3}{|c|}{ LSD. } & 0.99 & 0.89 & 2.80 & 0.21 & 0.78 \\
\hline \multicolumn{8}{|c|}{ Mean effect of foliar application } \\
\hline \multirow{3}{*}{\multicolumn{2}{|c|}{$\begin{array}{c}\text { Non Foliar } \\
\text { Foliar }(\mathrm{F})\end{array}$}} & & $37.88 \mathrm{~b}$ & $9.00 \mathrm{~b}$ & $54.15 \mathrm{~b}$ & $4.87 \mathrm{~b}$ & $21.71 \mathrm{~b}$ \\
\hline & & & $44.79 \mathrm{a}$ & $9.92 \mathrm{a}$ & $61.08 \mathrm{a}$ & $6.35 \mathrm{a}$ & $24.63 \mathrm{a}$ \\
\hline & & LSD & 2.52 & 0.67 & 4.22 & 0.16 & 0.54 \\
\hline \multicolumn{8}{|c|}{ Mean effect of water salinity $\mathrm{mg} / \mathrm{L}$} \\
\hline & \multirow{4}{*}{ Salinity (s) } & Cont. & $43.83 \mathrm{a}$ & $10.83 \mathrm{a}$ & $66.74 \mathrm{a}$ & $5.96 \mathrm{a}$ & $27.83 \mathrm{a}$ \\
\hline & & 1500 & $44.33 \mathrm{a}$ & $10.08 \mathrm{a}$ & $58.35 \mathrm{~b}$ & $5.74 \mathrm{~b}$ & $22.50 \mathrm{~b}$ \\
\hline & & 2500 & $43.92 \mathrm{a}$ & $8.92 \mathrm{~b}$ & $53.87 \mathrm{c}$ & $5.75 \mathrm{~b}$ & $22.92 \mathrm{~b}$ \\
\hline & & 3500 & $33.25 \mathrm{~b}$ & $8.00 \mathrm{~b}$ & $51.52 \mathrm{c}$ & $5.01 \mathrm{c}$ & $19.42 \mathrm{c}$ \\
\hline \multicolumn{3}{|c|}{ LSD. } & 2.31 & 1.03 & 0.32 & 0.09 & 1.57 \\
\hline \multirow{5}{*}{$\begin{array}{c}\text { Interactions } \\
\text { cv. x F } \\
\text { S X CV. } \\
\text { S X F } \\
\text { S X F X CV. }\end{array}$} & & & & & & & \\
\hline & & & n.s. & n.s. & n.s. & $*$ & $* *$ \\
\hline & & & $* *$ & $*$ & $*$ & $* *$ & $* *$ \\
\hline & & & $*$ & $* *$ & $* *$ & $* *$ & $*$ \\
\hline & & & n.s. & n.s. & n.s. & $* *$ & $*$ \\
\hline
\end{tabular}

Egypt. J. Soil Sci. 53, No.2 (2013) 
TABLE 3. Effects of foliar nutrition and water salinity levels on vegetative growth and yield components of the two genotypes of garlic during season of 2011/2012.

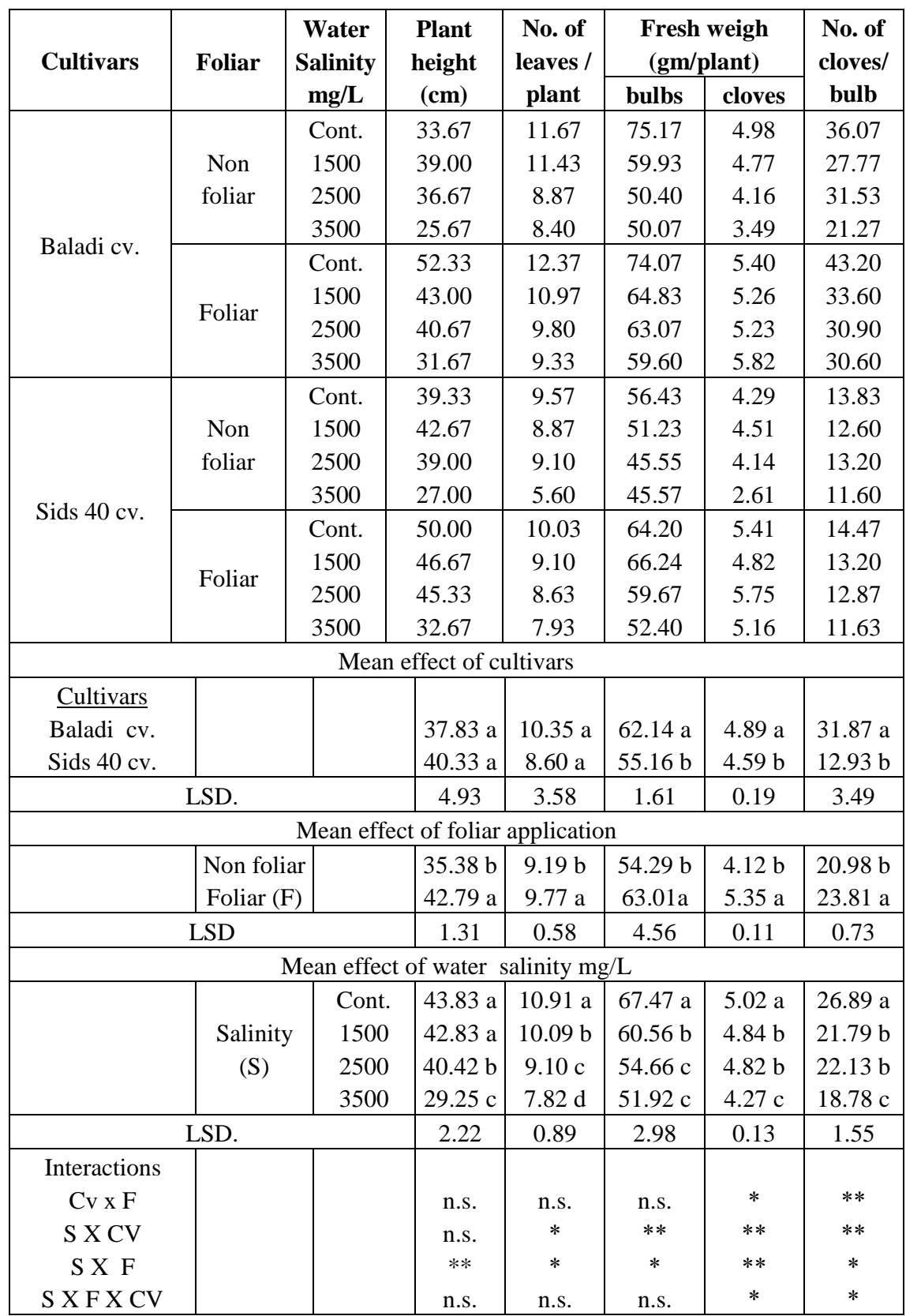

Egypt. J. Soil Sci. 53, No.2 (2013) 
RESPONSE OF TWO GARLIC CULTIVARS TO FOLIAR NUTRITION ... 213

TABLE 4. Effects of foliar nutrition and water salinity levels on N,P and $K$ uptake and protein content of the two genotypes of garlic.

\begin{tabular}{|c|c|c|c|c|c|c|}
\hline \multirow[b]{2}{*}{ Cultivar } & \multirow[b]{2}{*}{ Foliar } & \multirow{2}{*}{$\begin{array}{c}\text { Water } \\
\text { Salinity } \\
\text { mg/L }\end{array}$} & \multicolumn{3}{|c|}{ Uptake $\left(\mathrm{g} / \mathrm{kg}^{-1}\right)$} & \multirow{2}{*}{$\begin{array}{c}(\%) \\
\text { Protein }\end{array}$} \\
\hline & & & $\mathbf{N}$ & $\mathbf{P}$ & $\mathbf{K}$ & \\
\hline \multirow{8}{*}{ Baladi cv. } & \multirow{4}{*}{ Non foliar } & Cont. & 50.27 & 2.67 & 15.26 & 3.14 \\
\hline & & 1500 & 48.22 & 2.71 & 14.67 & 3.01 \\
\hline & & 2500 & 41.97 & 2.64 & 13.83 & 2.62 \\
\hline & & 3500 & 35.24 & 1.63 & 13.07 & 2.20 \\
\hline & \multirow{4}{*}{ Foliar } & Cont. & 54.50 & 2.82 & 16.46 & 3.40 . \\
\hline & & 1500 & 53.02 & 2.85 & 16.62 & 3.31 \\
\hline & & 2500 & 52.82 & 2.91 & 17.43 & 3.30 \\
\hline & & 3500 & 58.77 & 2.92 & 17.56 & 3.67 \\
\hline \multirow{8}{*}{ Sids $40 \mathrm{cv}$. } & \multirow{4}{*}{ Non foliar } & Cont. & 43.33 & 2.73 & 14.81 & 2.70 \\
\hline & & 1500 & 45.53 & 2.83 & 13.77 & 2.84 \\
\hline & & 2500 & 41.77 & 2.14 & 14.75 & 2.61 \\
\hline & & 3500 & 26.35 & 1.10 & 13.36 & 1.64 \\
\hline & \multirow{4}{*}{ Foliar } & Cont. & 54.60 & 2.96 & 18.04 & 3.41 \\
\hline & & 1500 & 48.67 & 2.88 & 17.71 & 3.04 \\
\hline & & 2500 & 58.10 & 2.86 & 17.28 & 3.63 \\
\hline & & 3500 & 52.13 & 2.92 & 16.93 & 3.25 \\
\hline \multicolumn{7}{|c|}{ Mean effect of cultivars } \\
\hline \multicolumn{7}{|l|}{ Cultivars } \\
\hline$\overline{\text { Baladi } \mathrm{cv} \text {. }}$ & & & $49.35 \mathrm{a}$ & $2.64 \mathrm{a}$ & $15.61 \mathrm{a}$ & $3.08 \mathrm{a}$ \\
\hline Sids $40 \mathrm{cv}$. & & & $45.97 \mathrm{~b}$ & $2.55 \mathrm{~b}$ & $15.83 \mathrm{a}$ & $2.87 \mathrm{~b}$ \\
\hline \multicolumn{3}{|c|}{ L.S.D. } & 0.65 & 0.002 & 0.65 & 0.15 \\
\hline \multicolumn{7}{|c|}{ Mean effect of foliar application } \\
\hline & Non foliar & & $41.24 \mathrm{~b}$ & $2.31 \mathrm{~b}$ & $14.19 \mathrm{~b}$ & $2.57 \mathrm{~b}$ \\
\hline & Foliar $(\mathrm{F})$ & & $54.03 \mathrm{a}$ & $2.89 \mathrm{a}$ & $17.26 \mathrm{a}$ & $3.37 \mathrm{a}$ \\
\hline \multicolumn{3}{|c|}{ L.S.D } & 0.52 & 0.04 & 0.30 & 0.51 \\
\hline \multicolumn{7}{|c|}{ Mean effect of water salinity $\mathrm{mg} / \mathrm{L}$} \\
\hline & \multirow{4}{*}{ Salinity (s) } & Cont. & $50.68 \mathrm{a}$ & $2.79 \mathrm{a}$ & $16.14 \mathrm{a}$ & $3.12 \mathrm{a}$ \\
\hline & & 1500 & $48.86 \mathrm{~b}$ & $2.82 \mathrm{a}$ & $15.69 \mathrm{~b}$ & $3.05 \mathrm{~b}$ \\
\hline & & 2500 & $48.67 \mathrm{~b}$ & $2.64 \mathrm{a}$ & $15.82 \mathrm{ab}$ & $3.04 \mathrm{~b}$ \\
\hline & & 3500 & $42.44 \mathrm{c}$ & $2.14 \mathrm{c}$ & $15.23 \mathrm{c}$ & $2.65 \mathrm{c}$ \\
\hline \multicolumn{3}{|c|}{ L.S.D. } & 0.66 & 0.04 & 0.34 & 0.35 \\
\hline \multirow{5}{*}{$\begin{array}{c}\text { Interactions } \\
\text { Cv x F } \\
\text { S X CV } \\
\text { S X F } \\
\text { S X F X CV } \\
\end{array}$} & & & & & & \\
\hline & & & $* *$ & $* *$ & n.s. & $* *$ \\
\hline & & & $* *$ & $* *$ & n.s. & $* *$ \\
\hline & & & $* *$ & $* *$ & $* *$ & $* *$ \\
\hline & & & $* *$ & $* *$. & $* *$ & $* *$ \\
\hline
\end{tabular}

\section{Foliar application}

Data in Tables 2 and 3 showed that foliar application using the commercial foliar fertilizer significantly increased plant height, No. of leaves and No. of cloves/ bulbs compared with those of the control plants. Foliar spray of nutrient solution had improved the fresh weight of both bulbs and cloves of the plants 
irrespective to their growth under non foliar fertilization. This may be attributed to the effect of nutrients in this fertilizer on raising the efficiency of photosynthesis and carbohydrate accumulation. It is obvious that micronutrients (iron, manganese, copper and zinc) are co-factor of many enzymes and play an important role in many biological processes such as photosynthesis reactions, nucleic acids metabolism, protein and carbohydrate biosynthesis as well as growth regulation (Negm et al., 2004). From the data in Tables 2 and 3, it is worthy to note that values of vegetative growth and yields bulb and clove in the first season were higher than those obtained in the second season as affected by foliar application, this may attributed to, the relative improvement in the soil properties.

The data in Table 4 indicate significant increases in $\mathrm{N}, \mathrm{P}$ and $\mathrm{K}$ uptakes by cloves of the two cultivars of garlic and protein content as influenced by foliar application of nutrient solution in comparison with control. This would be due to the contents of macro and microelements in the formulation of the foliar fertilizer and its simulative effect. The role of micronutrients may be due to activation of several enzymes which enhance plant growth and endogenous parameters of plant involved in the main metabolic process especially those due to energy co-enzymes, carbohydrates and protein metabolism and improving biosynthetic activity. These results are in agreement with that obtained by Hassan et al. (2004) and Shaheen et al. (2008).

\section{Irrigation water salinity}

Data presented in Tables 2 and 3 showed that vegetative growth of garlic plants, plant height and No. of leaves, were statistically decreased by increasing irrigation water salinity. These results were similar and statistical in the two seasons of the experiment. Irrigation by well water (control) and saline water of level $1500 \mathrm{mg} / \mathrm{L}$ resulted in the tallest plant in both seasons. Green yield followed the same trend of vegetative growth as affected by salinity. The highest fresh weight of bulbs resulted from the lowest salinity level $(1500 \mathrm{mg} / \mathrm{L})$ was shown in both seasons. In other words, the shortest plants, number of leaves, fresh weight of bulb and cloves and No. of cloves/ bulbs, decreased significantly compared with control with the highest salinity level $(3500 \mathrm{mg} / \mathrm{L})$. Other vegetable crops reflected decrease in total green yield when irrigated by saline water (Francois and Maas, 1994 on garlic). Amorim et al. (2002) reported reduction in all yield components (bulb weight and diameter and plants / unit area) for increasing salinity for garlic. Salinity stress retards plant growth through its influence on several plant physiological processes, e.g., osmotic adjustment, nutrient uptake, photosynthesis, organic soluble accumulation, alteration in respiration rates and soil water potential (Pessarakli, 1994).

Table 4 showed that macro-elements (N, P and $\mathrm{K}$ ) uptake and protein\% content of garlic plants were significantly decreased by increasing irrigation water salinity up to its highest level. But, there were no statistical differences 
among 1500 and $2500 \mathrm{mg} / \mathrm{L}$ levels for N, P and $\mathrm{K}$ uptakes and protein\% content. The lowest values of $\mathrm{N}, \mathrm{P}$ and $\mathrm{K}$ uptakes and protein \% content were observed by the highest salinity level. The decrease in $\mathrm{N}, \mathrm{P}$ and $\mathrm{K}$ uptakes might be due to the gradual decrease in the vegetative growth of garlic plants. Under the conditions of salt stress, the uptake of nitrogen is often disrupted and numerous studies have shown that excess salts can reduce the accumulation of nitrogen in plants (Abdelgadir et al., 2010 and Wahid et al., 2004). Increase in uptake and accumulation of $\mathrm{Cl}^{-}$is accompanied by a reduction in the concentration of $\mathrm{NO}_{3}^{-}$ in eggplant (Savvas and Lenz, 2000). There are authors who had attributed this reduction to the antagonism between $\mathrm{Cl}^{-}$and $\mathrm{NO}_{3}{ }^{-}$(Bar et al., 1997). In most cases, excess of salts in soil solution leads to a reduction in phosphorus concentration in the tissues of plants. Kochian (2000) suggests that the reduction of the availability of phosphorus in saline soils is the result of the activity of ions antagonists, which can reduce the activity of phosphate and phosphate transporters of both high and low affinity, which are necessary for the uptake of phosphorus (Kochian, 2000). The data showed that the $\mathrm{K}$ uptake was decreased as salinity increased from 1500 to $3500 \mathrm{mg} / \mathrm{L}$. The decrease in the $\mathrm{K}$ uptake in plants may be related to attendant increase in the uptake of $\mathrm{Na}^{+}$that was related to its higher level in water of irrigation. This result is in agreement with those of others ( Mass and Hoffman, 1977 and Maksimović et al., 2010)

\section{Interactions effect}

Weight of garlic cloves and No. of cloves/bulb were statistically affected by the combined effect of cultivars and foliar fertilizers (Table 2 and 3). These results were similar and statistical significant in the two seasons of the experiment. Also, the interaction between cultivars and foliar fertilizers had highly significant effect on $\mathrm{N}$ and $\mathrm{P}$ uptake by cloves and protein content of the two cultivars of garlic (Table 4).

Data in Tables 2 and 3 show the vegetative growth, yield and its components of the two cultivars of garlic (sids 40 and Baladi) expressed as plant height, No. of leaves / plant, bulb and cloves weight, No. of cloves/ bulb were statistically affected by the combined effect of cultivars and salinity of irrigation water in two seasons except plant height in the second season. The interaction between cultivars and salinity had highly significant effect on $\mathrm{N}$ and $\mathrm{P}$ uptake by cloves and on protein content of garlic plants. The results in Table 4 indicated that baladi $\mathrm{cv}$. was the best in its nutrient uptake ( $\mathrm{N}$ and $\mathrm{P}$ ) and protein content compared with sids $40 \mathrm{cv}$. with increasing salinity from 1500 to $3500 \mathrm{mg} / \mathrm{L}$.

The interaction between foliar application and salinity had highly significant effect on vegetative growth, yield and its components of the two garlic cultivars. Foliar application of nutrients was found to be effective in mitigating the adverse effects of salinity on growth of garlic plants. It significantly improved plant water status which might have contributed to better growth of the plants under salt condition. Salinity significantly reduced the growth of garlic plants (Tables 2 and 3). Foliar spray of nutrient solution had offset the toxic effects of salinity to 
various extents and improve the shoot fresh weight of both garlic plants irrespective to their growth under non saline or saline conditions (Akram et al., 2009 and Jabeen \& Ahmad, 2011) also reported an improvement in growth of sunflower and safflower plants, respectively due to foliar applied nutrients under salt stress. The beneficial effects of nutrient solution may be due its content of calcium which prevents the effects of salinity. The interaction between foliar application and salinity had highly significant effect on $\mathrm{N}, \mathrm{P}$ and $\mathrm{K}$ uptake by cloves and protein\% content of garlic plants. Data in Table 3 showed that N, P and $\mathrm{K}$ uptake by cloves and protein $\%$ content of Baladi garlic plants decreased to $35.24,1.63$ and $13.07 \mathrm{~g} \mathrm{~kg}^{-1}$ and $2.20 \%$, respectively with increasing salinity from 1500 to $3500 \mathrm{mg} / \mathrm{L}$ non foliar application. While, N, P and K uptake by cloves and protein\% content of Baladi garlic plants increased to 58.77, 2.92, $17.56 \mathrm{~g} \mathrm{~kg}^{-1}$ and $3.67 \%$, respectively with salinity $(3500 \mathrm{mg} / \mathrm{L})$ and foliar application of nutrient solution. These results suggest that foliar application of nutrient solution ameliorate the negative effects of salinity by enhancing the availability of some other essential cations and phytohormones which play an important role in regulation of stomata (Sage and Reid, 1994). Similar results were also reported by Sultana et al. (2001). Increased salt concentrations can lead to a reduction in evapotranspiration, disturbances in mineral nutrition of plants, the plant hormone imbalances, and to the formation of freer radicals that damage cell membranes (Qi and Spadling, 2004). Expansion of leaves may be impaired and their anatomical properties altered. The high concentration of salts in the soil solution may reduce the removal of nitrogen, phosphorus and potassium so it is necessary to add these elements in the form of fertilizers.

The interaction between cultivars, foliar fertilizers and salinity had significant and highly significant effect on fresh weight of cloves and No. of cloves/ bulbs, in the two seasons. The interaction had highly significant effect on $\mathrm{N}, \mathrm{P}$ and $\mathrm{K}$ uptake by cloves of garlic plants. For Baladi cv higher N, P and K uptake (58.77, 2.92 and $\left.17.56 \mathrm{gkg}^{-1}\right)$ and higher protein $(3.67 \%)$ were observed in treatment foliar nutrient solution with salinity $3500 \mathrm{mg} / \mathrm{L}$. On the other hand, for sids 40 $\mathrm{cv}$. higher nitrogen uptake and protein content $\left(58.10 \mathrm{gkg}^{-1}\right.$ and $\left.3.63 \%\right)$, respectively were observed in the treatment of foliar nutrient solution with salinity of $2500 \mathrm{mg} / \mathrm{L}$, while $\mathrm{P}$ and $\mathrm{K}$ uptake 2.96 and $18.04 \mathrm{gk} / \mathrm{g}^{-1}$ were observed in treatment of foliar nutrient solution without salinity treatments.

\section{Conclusion}

From the results of the present investigation it recommended to use cv. Baladi when irrigation water with salinity level up to $3500 \mathrm{ppm}$ in order to overcome or reduce the toxic effect of salinity and to obtain relatively good plant growth, good quality and yield, as well as good chemical composition compared with the other cultivar cv. sids 40 . Thus, cv. Baladi was the most salt tolerant compared with cv. sids 40. It is clear that, the combined effect among Baladi cultivar and salinity concentrations of irrigation water gave positive results with

Egypt. J. Soil Sci. 53, No.2 (2013) 
respect to the above mentioned parameters. Foliar spray of nutrient solution have offset the toxic effects of water salinity to various extentsand improve the shoot fresh weight of both garlic plants irrespective to their growth under non saline or saline conditions.

\section{References}

Abdelgadir, E.M., Fadul, E.M., Fageer, E.A. and Ali, E.A. (2010) Response of wheat to nitrogen fertilizer at reclaimed high terrace salt-affected soils in Sudan. Journal of Agriculture \& Social Sciences 6: 43-47.

Akram, M.S., Ashraf, M. and Akram, N.A. (2009) Effectiveness of potassium sulfate in mitigating salt-induced adverse effects on different physio-biochemical attributes in sunflower (Helianthus annuus L.). Flora 204 (6): 471-483.

Amorim, J.R., Fernandez, P.D., Gheyi, H.R. and Azevedo, N.C. (2002) Effect of irrigation water salinity and its mode of application on garlic growth and production (in French). Pesq.Agropec.Bras. Brasilia 37: 167-76.

Bar, Y., Apelbaum, A., Kafkafi, U. and Goren, R. (1997) Relationship between chloride and nitrate and its effect on growth and mineral composition of avocado and citrus plants. Journal of Plant Nutrition 20: 715-731.

Black, C. A., Evans, D. D., Ensminger, L. E., White, G. L. and Clark, F.E. (1981) "Methods of Soil Analysis", Part 2, pp. 1-100, Agron. Inc. Madison.Wisc., USA.

Epstein, E., Norlyn, J. D., Rush, D. W., Kingsburg, R. W., Kelly, D. B. and Cunmghan, G. A. (1980) Saline cultivar of crops: A genetic approach. Science 210, 399.

Francois, L. E. and Maas, E. V. (1994) Crop response and management of salt- affected soils. In: "Handbook of Plant and Crop Stress", M. Pessarakli (Ed.), pp. 449-459, Marcel Dekker Inc., New York, NY.

Francois, L. E. (1994) Yield and quality response of salt-stressed garlic. Hort. Science 29: 1314-1317.

Ghassemi, F., Jakeman, A. J. and Nix, H. A. (1995) Salinisation of land and water resources; Human causes, extent, management and case studies.UNSW Press, Sydney, Australia and CAB International, Wallingford, UK.

Gomez, K. A. and Gomez, A.A. (1984) "Statistical Procedures for Agric. Research", $2^{\text {nd }}$ ed., pp. 28-92, John Willey, New York.

Hassan, M.A., Mansour, A. A. and Desouky, H. I. (2004) Effect of N fertilization and foliar application of liquid organic extract on cotton yield and its components. Egypt. J. Appl. Sci. 19: 334-346. 
Hassan, M. A., El- Tohamy, M. A. and Mohamed, A. A. A. (2011) Response of garlic cultivated in alkaline soil to foliar application of some plant nutritive compounds. Egypt. J. of Appl. Sci. 26 (5).

Hassan, M. M., Abd El-Khalik, I. A. and Abo El- Azayem, A. I. (2001) Salt tolerance of apricot tree . Egypt. J. Hort. 28 (1): 91-99.

Hegab, A.A., Mahgoub, M. A. and Youssef, A. E. (1987) Effect of iron, manganese and zinc on yield, cotton grade and quality of fiber properties of Egyptian cotton. Agric. Res. Rev. 65: 645-657.

Jabeen, N. and Ahmad, R. (2011) Foliar application of potassium nitrate affects the growth and nitrate reductase activity in sunflower and safflower leaves under salinity. Nat. Bot. Horti. Agrobo. 39 (2): 172-178.

Jackson, M. L. (1973) "Soil Analysis", pp. 1-15,Constable Co. Ltd., London.

Kochian, L.V. (2000) Molecular physiology of mineral nutrient acquisition, transport and utilization. In: "Biochemistry and Molecular Biology of Plants", B.B. Buchan, W. Gruissen and R.L. Jones (Ed.), pp.1204-1249, American Society of Plant Physiology, Rockville, pp. EUA.

Lowther, J.R. (1980) Use of single $\mathrm{H}_{2} \mathrm{SO}_{4}-\mathrm{H}_{2} \mathrm{O}_{2}$ disgest for the analysis of Pinusradiata, needles. Commun.Soil Sci. Plant Analysis 11: 175-188.

Maas, E.V. and Hoffman, G.J. (1977) Crop salt tolerance-current assessment. Proc. Amer. Soc. Civil Eng. J. Irrig.\& Drainage Div. 103 (IR- 2): 115-134.

Maksimović, I., Putnik-Delić, M., Gani, I., Marić, J. and Ilin, Ž. (2010) Growth, ion composition, and stomatal conductance of peas exposed to salinity. Central European Journal of Biology 5: 682-691.

Negm, M. A., Zaki, R. N. and El - Meneasy, A. I. A. (2004) Effect of iron and zinc as foliar application on sorghum grown in calcareous soil. Egypt. J. Soil. Sci. 44, 465475 .

Pessarakli, M. (1994) Physiological responses of cotton (Gossypium hirsutum L.) to salt stress. In : "Handbook of Plant and Crop Physiology", M. Pessarakli (Ed.), pp. 679693, Marcel Dekker, Inc., New York.

Qi, Z. and Spadling, E.P. (2004).Protection of plasma membrane K+ transport by the salt overly sensitive $\mathrm{Na}^{+}-\mathrm{H}^{+}$antiporter during salinity stress. Plant Physiology 136: 2548-2555.

Egypt. J. Soil Sci. 53, No.2 (2013) 
Sage, R.F. and Reid, C.D. (1994) Photosynthetic response mechanisms to environmental change in C3 plants. In: "Plant-Environment Interactions", R.E. Wilkinson (Ed.), pp. 413-499. Marcel Dekker, New York, NY.

Savvas, D. and Lenz, F. (2000) Effects of $\mathrm{NaCl}$ or nutrient-induced salinity on growth, yield and composition of eggplants grown in rockwool. Scientia Horticulturae 84: 37-47 .

Sendecor, G. H. and Cochran, W. C. (1980) "Statistical Methods", $7^{\text {th }}$ ed., Iowa State University Press, Ames., Iowa, U.S.

Shaheen, A.M., Fatma, A. Rizk and Singer, S.M. (2008) The effect of foliar application of urea andmore-beans mixture on the growth and yield and characteristics of two pea cultivars. Egypt. J. Appl. Sci. 23: 341-351.

Sultana, N., Ikeda, T. and Kashem, M.A (2001) Effect of foliar spray of nutrient solutions on photosynthesis, dry matter accumulation and yield in sea water-stressed rice. Envirn.and Exp. Bot. 46: 129-140.

Wahid, A., Hameed, M. and Rasul, E. (2004) Salt-induced injury symptom, changes in nutrient and pigment composition and yield characteristics of mungbean. International Journal of Agricultural Biology 6: 1143-52.

(Received 16 /6 / 2013; accepted $31 / 10 / 2013$ ) 


\section{إستجابة صنفين من الثوم للرش بمحلول مغذى تحت ظروف الرى

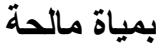

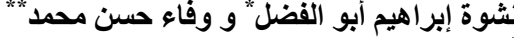

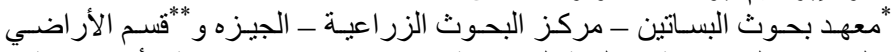

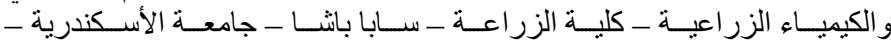
الأسكندرية- مصر. الزعر.

أجريـت هـذه الدر اســة خـلال الموسـين الثـتويين لعـامى 2010 - 2011 2011/ 2011-

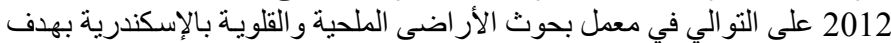

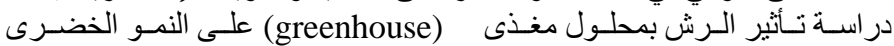

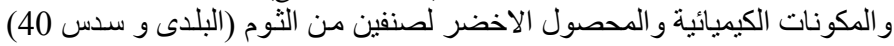

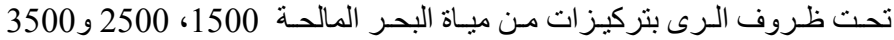
ملجر ام / لتر بالإضافة إلى الكنترول.

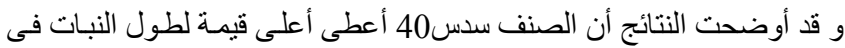

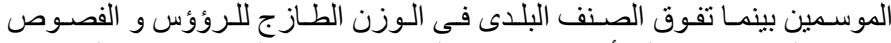

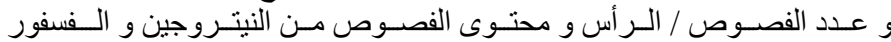

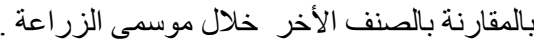

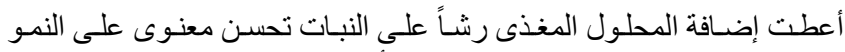

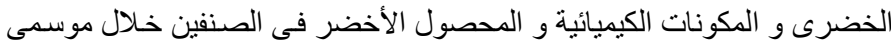

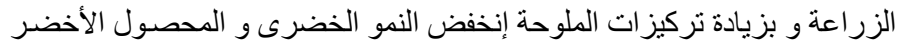

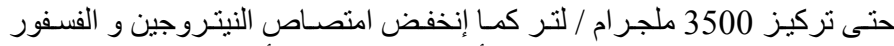

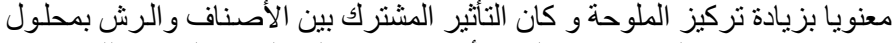

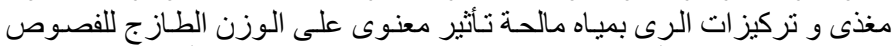

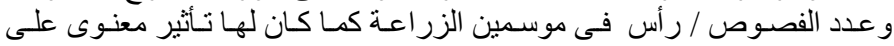
إمنصاص النبتروجين و الفسفور و البوتاسيو و والمحتوى من البروتين.

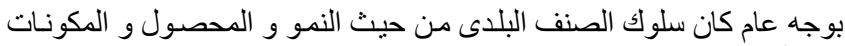
الكيميائية أفضل عام تحت ظروف الرش بمحلول مغذى و الرى بمياه مالحة الفول 